\title{
PEMIKIRAN RADEN AJENG KARTINI TENTANG PENDIDIKAN PEREMPUAN DAN RELEVANSINYA TERHADAP PENDIDIKAN ISLAM
}

\author{
Muthoifin, Mohamad Ali, Nur Wachidah \\ Magister Pendidikan Islam Universitas Muhammadiyah Surakarta \\ E-Mail: mut122@ums.ac.id
}

\begin{abstract}
Raden Ajeng Kartini is one of first feminist in Indonesia who is installed as national heroine and her birthday is celebrated by Indonesia nation. The hardest Kartini's struggle was for education, because she was sure that one of the instruments of respecting woman role in improving civilization. Based on the explanation, this study aim is to (1) describe Raden Ajeng Kartini's idea of woman education, and (2) analyze the Raden Ajeng Kartini's idea relevance of woman education for developing Islamic education. This research is library research by using historical and biography approaches by retelling and reexpressing the important history and event in the Kartinis's life. This research is analyzed by describing the Kartini's consideration of education which manifested and had the relevance of the theory. Kartini's idea of education is critics reaction based on every problem which faced by her thought education experiences which were gotten, so that it appears practical concept of woman education. Kartini's struggle was not just and idea, because Kartini was brave to stride in opening woman school even it had contradiction with culture. The effect on next development, Kartini's struggle became stimulation in developing education, especially Islamic education which develops very quickly by appearing woman school (Islamic boarding school) and the progress of Islamic ideas by appearing many religious organizations after Kartini's death.
\end{abstract}

Keywords: woman education, R.A. Kartini, Islamic education

Abstrak: Raden Ajeng Kartini adalah seorang tokoh feminis pertama Indonesia yang dikukuhkan sebagai pahlawan nasional dan hari lahirnya diperingati oleh seluruh rakyat Indonesia.Kartini seorang pejuang kemerdekaan perempuan.Perjuangan Kartini yang paling keras adalah pendidikan, karena Kartini yakin hanya pendidikan alat satu-satunya untuk mengangkat derajat peremuan dan menyadarkan masyarakat tentang pentingnya peran perempuan dalam membangun peradaban. Berdasar hal itu, maka penelitian ini bertujuan untuk (1) mendeskripsikan pemikiran Raden Ajeng Kartini tentang pendidikan perempuan, dan (2) menganalisis relevansi pemikiran pendidikan perempuan Raden Ajeng Kartini bagi pengembangan pendidikan Islam. Penelitian ini merupakan jenis penelitian kepustakaan yang menggunakan pendekatan historis dan biografi dengan menceritakan dan mengungkap kembali sejarah dan peristiwa penting dalam kehidupan Kartini. Penelitian ini menggunakan analisis isi dalam menganalisis data penelitian, yakni mendeskripsikan pemikiran pendidikan Kartini yang termanifestasikan dan memiliki relevansi teori yang jelas. Pemikiran Kartini tentang pendidikan merupakan reaksi kritis atas setiap permasalahan yang dihadapinya berdasar pengalaman-pengalaman edukatif yang diperoleh sehingga melahirkan konsep praktis tentang pendidikan perempuan.Perjuangan Kartini bukan sebatas ide, karena Kartini telah berani melangkah, membuka sekolah perempuan meski bertentangan dengan adat.Akibat pada perkembangan selanjutnya, perjuangan Kartini menjadi stimulan pengembangan pendidikan, khususnya pendidikan Islam yang mengalami perkembangan sangat cepat dengan tumbuhnya sekolah-sekolah perempuan (pesantren) dan kemajuan pemikiran-pemikiran Islam dengan tumbuhnya berbagai organisasi keagamaan setelah wafatnya Kartini.

Kata Kunci: pendidikan perempuan, R.A. Kartini, pendidikan Islam 


\section{PENDAHULUAN}

Pembicaraan mengenai perempuan sangat menarik, tidak ada habisnya untuk diperbincangkan. Perempuan mungkin tidak bisa seluruhnya menduduki "high profile", namun isu-isu yang menyangkut perempuan seperti kedudukan, peranan, kegiatan, kesetaraan, dan kemandiriannya masih menjadi isu yang kontroversial dan emosional. ${ }^{1}$ Sebelum perkembangan abad ke-20, perempuan tidak bisa disejajarkan dengan laki-laki dalam hal apapun, khususnya pendidikan.Perempuan tidak memperoleh hak pendidikan dan melakukan interaksi sosial dengan masyarakat. Perempuan hanya bertugas di dalam rumah, sebagai istri yang "baik", tanpa adanya kebebasan, baik dalam pemikiran maupun tingkah laku sebagai manusia seutuhnya yang diberikan potensi. ${ }^{2}$ Melihat permasalahan di atas, tergugahlah beberapa tokoh perempuan seperti: Cut Nyak Dien, Raden Dewi Sartika, Rohana Kudus, Rahmah El-Yunusiyah, dan Raden Ajeng (R.A.) Kartini, untuk mengubah pola pikir masyarakat tentang perempuan, dan mengubah kedudukannya sejajar dengan laki-laki, terlebih dalam hal pendidikan.

R.A. Kartini yang kemudian disebut sebagai Kartini, merupakan salah satu tokoh yang berbeda dari beberapa tokoh lainnya, karena dengan keberhasilan dan semangat perjuangan emansipasinya dijadikan sebagai bentuk kepahlawanan dan dikukuhkannya beliau sebagai pahlawan Republik Indonesia (RI) yang tertera dalam Surat Keputusan Presiden RI Nomor 108 pada tanggal 02 Mei 1964 dan setiap tanggal lahirnya 21 April diperingati sebagai Hari Kartini. Diberikannya gelar tersebut menuai banyak kritik di kalangan masyarakat.Perjuangan Kartini dianggap hanya sebatas perjuangan lokal masyarakat Jawa khususnya Kabupaten Jepara

1 Khofifah Indar Parawansa, Menteri Negara Pemberdayaan Perempuan Republik Indonesia, Kata Sambutan dalam Maftuchah Yusuf, Perempuan Agama dan Pembangunan, Wacana Kritis atas Peran dan Kepemimpinan Wanita (Yogyakarta: Lembaga Studi dan Inovasi Pendidikan, 2000), hlm. V.

2 Abdul Mu'thi, Mitos-mitos Perempuan Kurang Akal (Yogyakarta: Gama Media, 2002), dalam "Pemahaman Islam dan Tantangan Keadilan Jender”, hlm. 54. saja. ${ }^{3}$ Perjuangan Kartini juga dianggap memiliki kepentingan subjektif Belanda dengan adanya politik etis. ${ }^{4}$ Bahkan Hasja W. Bachtiar beranggapan bahwa perjuangan Kartini hanya sebatas ide. ${ }^{5}$

Selain itu, desas-desus keagamaan Kartini banyak dipertanyakan.Riwayat keagamaan Kartini seakan disembunyikan dari penglihatan publik.Masyarakat beranggapan bahwa Kartini menganut paham westernisasi dalam pemikirannya tanpa memperhatikan aspek religius.Tetapi, jika ditelisik lebih jauh dari keturunannya. Kartini mempunyai keturunan keluarga yang taat dengan agamanya, Islam. ${ }^{6}$

Sejak kecil Kartini dididik dengan pendidikan Barat oleh Ayahnya dan berkawan dengan anak-anak Belanda. Namun, pendidikan itu tidak membuatnya menganut pemahaman orang kulit putih. Nasionalisme Kartini merupakan refleksi sosial yang kritis dari seorang perempuan Indonesia yang didasarkan pada religiusitas, kebijaksanaan, keindahan, dan kemanusiaan yang mengandung nilai-nilai universal seperti, pendidikan, solidaritas sosial, persatuan kaum muda, dan persamaan derajat. ${ }^{7}$

Pada masa Kartini yang sangat kental akan budaya Jawa menempatkan perempuan sebagai makhluk kelas dua setelah laki-laki. Perempuan tidak memiliki

3 Hanni Sofia, Surat Kartini antara Inspirasi dan Apatisme Bangsa (Koran online Antara Sumsel: 2014), http://www.antarasumsel.com/berita/285823/ surat-kartini-antara-inspirasi-dan-apatisme-bangsa diunduh 01 Oktober 2016, pukul: 11.27 WIB. Tulisan ini juga menginformasikan bahwa Ibu Negara Sinta Nuriyah Wahid sempat mengusulkan untuk mengubah hari Kartini menjadi Hari Perempuan.

4 Nurul Khawari, Kartini dan Perempuan Muda Indonesia (Koran Online Joglo Semar: 2012) http:// www.edisicetak.joglosemar.co/berita/kartini-danperempuan-muda-indonesia-71881.html, diakses 11 Oktober 2016.

5 LPPI Makassar, R.A. Kartini Versus Aisyah We Tenriolle, 2013, http://www.lppimakassar. com/2013/05/ra-kartini-versus-aisyah-we-tenriollle. html, diakses 11 Oktober 2016.

6 Nur Said, Politik Etis Kepahlawanan R.A. Kartini: Menguak Spiritualisme Kartini yang Digelapkan (Jurnal PALASTREN, 2014), vol. 7, No. 2, hlm. 361364.

7 Sudrajat, Kartini: Perjuangan dan Pemikirannya (Jurnal Mozaik, Januari 2007), vol. 2, No. 2, Universitas Negeri Yogyakarta, hlm. 10. 
kekuasaan atas dirinya sendiri.Perempuan tidak memiliki kebebasan untuk mengaktualisasikan diri.Tugas perempuan hanya di dapur, sumur, dan kasur, karena perempuan tersubordinasi dari kaum lakilaki.perempuan tak ubahnya sebagai budak dari tuannya, dimana segala kehidupan perempuan telah diatur sedemikian rupa orang tua dan penuh kepatuhan khususnya pada golongan bangsawan Jawa. ${ }^{8}$

Persamaan derajat yang digagas oleh Kartini merupakan bentuk emansipasi, salah satunya dalam bidang pendidikan, dimana perempuan seharusnya mempunyai hak belajar dan hak bersosial masyarakat, sehingga saat ini peran perempuan Indonesia menjadi sangat kompleks, baik dibidang pendidikan, ekonomi, budaya, maupun politik. Namun, perkembangan globalisasi yang semakin meluas, memberikan pemahaman emansipasi yang keliru terkait kesetaraan gender. Para feminis dari beberapa dekade terakhir menyuarakan, memperjuangkan, dan melawan segala bentuk penindasan pada kaum perempuan dengan pelbagai cara, bahkan berusaha menyamakan baik kedudukan maupun peran laki-laki dan perempuan tanpa memandang gender sehingga banyak terjadi penyimpangan yang menyalahi kodrat perempuan.

Berdasar latar belakang di atas, maka penelitian ini bertujuan untuk (1) mendeskripsikan pemikiran Raden Ajeng Kartini tentang pendidikan perempuan, dan (2) menganalisis relevansi pemikiran pendidikan perempuan Raden Ajeng Kartini bagi pengembangan pendidikan Islam.

Penelitian ini menggunakan teori-teori pendidikan perempuan yang dianggap sesuai untuk menjawab pertanyaan penelitian. Berdasar beberapa definisi pendidikan oleh Ki Hajar Dewantara, Sugarda Purkawatja, ${ }^{9}$ Ahmad D. Marimba, ${ }^{10}$ dan UU Sidiknas, ${ }^{11}$ maka dapat disimpulkan

\footnotetext{
8 Sartono, Sudewo, dan Suhardjo, Perkembangan Peradaban Priyayi (Yogyakarta: Gajah Mada University Press, 1987), hlm 100.

9 Abuddin Nata, Filsafat Pendidikan Islam. Jakarta: Logos Wacana Ilmu, 1997, hlm. 9-10.

10 Hasan Basri, Landasan Pendidikan (Bandung: Pustaka Setia, 2013), hlm. 15.

11 UU sidiknas no. 20 tahun 2003, Bab 1, Pasal 1.
}

pendidikan merupakan upaya yang dilakukan untuk memberikan pemahaman dan pengalaman agar anak didik cakap dan terampil dalam mengembangkan potensi dirinya, baik bagi individu itu sendiri, maupun bagi masyarakat luas, berbangsa, dan bernegara.

Pendidikan merupakan suatu sistem, sehingga di dalamnya terdapat komponenkomponen yang saling terkait satu sama lain. Komponen-komponen tersebut terdiri dari: tujuan pendidikan, pendidik, materi pendidikan, metode pendidikan, dan lingkungan pendidikan. ${ }^{12}$

Pendidikan dilakukan dengan tidak melakukan diskriminasi terhadap anak laki-laki maupun perempuan.berdasar UU 1945 pasal 31 ayat 1 mengatakan bahwa tiap-tiap warga negara berhak mendapat pengajaran. ${ }^{13}$ Prinsip dalam demokrasi pendidikan mencakup tiga hal sebagai berikut: (1) hak asasi setiap warga negara untuk memperoleh pendidikan, (2) hak memperoleh kesempatan yang sama bagi warga negara untuk memperoleh pendidikan, (3) hak dan kesempatan atas dasar kemampuan mereka. ${ }^{14}$ Demokrasi pendidikan dalam pengajaran tanpa melupakan penanaman ideologi gender agar masing-masing gender mengetahui dimana posisi dan kedudukannya sehingga mengurangi ketimpangan gender. Peran yang paling signifikan dalam membentuk ideologi gender adalah guru kelas dan buku teks. ${ }^{15}$

Secara resmi dalam rencana pembangunan lima tahun yang keenam (tahun 1994-1999), disusun sasaran pengembangan perempuan berdasarkan

12 Teori ini diambil dari beberapa sumber, diantaranya: Suryosubroto, Beberapa Aspek Dasar-dasar Kependidikan (Jakarta: Rineka Cipta, 2010), hlm. 16-23, Wiji Suwarno, Dasar-dasar Ilmu Pendidikan (Yogyakarta: ar-Ruzz, 2006), hlm. 37-48, Hasan Basri, Landasan Pendidikan (Bandung: Pustaka Setia, 2013), hlm. 28-37, Fuad Ihsan, Dasar-dasar Kependidikan Komponen MDMK (Jakarta: Rineka Cipta, 2010), hlm. 8-10.

13 Hasbullah, Dasar-dasar Ilmu Pendidikan (Jakarta: Raja Grafindo Persada, 1999), hlm. 241.

14 Ibid, hlm. 245-246.

15 Ida Siti Herawati "Pendidikan yang Berperspektif Gender pada Jenjang Sekolah Dasar" dalam Sugiarti dkk, Pembangunan dalam Perspektif Gender (Malang: UMM Press, 2003), hlm. 225-235. 
arah dari GBHN Tahun 1998, menyatakan bahwa perempuan, sebagai sumber daya negara, maupun sebagai sumber daya insan pembangunan di segala bidang. Selanjutnya, dinyatakan bahwa kemampuan perempuan perlu dikembangkan dan teknologi, keterampilan, dan ketahanan mental spiritual agar dapat memanfaatkan kesempatan berperan aktif di segala bidang termasuk dalam pengambilan keputusan serta menghadapi perubahan baik dalam masyarakat maupun di dunia internasional. ${ }^{16}$ Peran perempuan dalam pembangunan adalah peran seperti yang dinyatakan di dalam ketetapan MPR Nomor IV Tahun 1978.Ketetapan MPR tersebut sebagai landasan perjuangan bangsa yang menyatakan secara jelas, bahwa peran perempuan adalah sebagai pembina kesejahteraan rumah tangga, pembina generasi muda, dan peserta dalam setiap pembangunan masyarakat, dan negara. ${ }^{17}$

Teori gender yang memberikan pengertian tentang perbedaan gender antara laki-laki dan perempuan dalam penelitian ini menggunakan teori nature/nurture dan teori sosial dalam masyarakat. Teori nature merupakan teori yang mendasarkan perbedaan gender pada fungsi biologisnya yang menyebabkan perbedaan peran dalam masyarakat, sedangkan teori nurture menyatakan bahwa adanya diferensiasi peran antara laki-laki dan perempuan disebabkan karena faktor budaya. ${ }^{18}$

Teori sosial yang dikemukaan dan dianggap penting adalah teori struktural fungsional dan teori sosial konflik. Teori tersebut merupakan pengadopsian terhadap teori sosial yang mendekati permasalahan gender, karena tidak terdapat teori khusus tentang gender, sehingga teori banyak dikembangkan menggunakan teori sosiologi.Teori struktural fungsional

16 Suhaenah Suparno, Wanita dan Pendidikan, Kasus di Indonesia, dalam "Wanita dalam Masyarakat Indonesia Akses, Pemberdayaan, dan Kesempatan", (Yogyakarta: Sunan Kalijaga Press, 2001), hlm. 326.

17 Maftuchah Yusuf, Perempuan Agama dan Pembangunan Wacana Kritis atas Peran dan Kepemimpinan Wanita, (Yogyakarta: Lembaga Studi dan Inovasi Pendidikan, 2000), hlm. 4-5.

18 Ratna Megawangi, Membiarkan Berbeda? Sudut Pandang Baru tentang Relasi Gender (Bandung: Mizan, 1999), hlm. 95-98 dan 102-103. dipopulerkan oleh Robert K. Merton dan Talcot Parson, sedang teori sosial banyak dipengaruhi oleh pemikiran Karl Max, sehingga banyak melahirkan teori-teori feminis. ${ }^{19}$

Islam memandang perempuan sebagai makhluk istimewa yang diciptakan Allah swt.Datangnya Islam memberikan kebebasan dan kemerdekaan kepada perempuan terlebih dalam hal kebebasan memperoleh pendidikan. Pandangan Islam terhadap perempuan dapat dilihat dalam beberapa hal seperti berikut: 1) kedudukan perempuan dalam Islam, dapat dilihat dari sejarah sebelum dan setelah kedatangan Islam, selain itu juga terdapat ayat AlQuran yang menjelaskan kedudukan perempuan yaitu Q.S. Al-Hujurat ayat 13 dan Q.S. An-Nisaa ayat 34 yang ditafsirkan dari beberapa tafsiran, 2) Dasar Pendidikan Perempuan yang dapat dilihat dalam Q.S. Az-Zumar ayat 9, 3) Tujuan pendidikan perempuan yang bertitik tolak pada tujuan pendidikan Islam yaitu menjadikan peserta didik sebagai insan kamil dan khalifah fil ardhi, 4) Peran pendidikan perempuan dibagi menjadi dua, yaitu: peran dalam keluarga dan peran dalam masyarakat. ${ }^{20}$

\section{METODE}

Penelitian ini merupakan jenis penelitian kepustakaan yang menggunakan paradigma kulitatif, dimana ciri penelitian

19 Teori-teori di atas dapat dilihat dalam referensi sebagai berikut: Margareth M. Poloma, Sosiologi Kontemporer (Jakarta: PT. Raja Grafindo Persana, 1994), hlm. 2832, Doyle Paul Johnson, Teori Sosiologi Klasik dan Modern (Jakarta: PT Gramedia Pustaka Utama, 1990), hlm.122-123, dan Ratna Megawangi, Membiarkan Berbeda? Sudut Pandang Baru tentang Relasi Gender (Bandung: MIZAN, 1999), hlm. 65-103.

20 Teori-teori di atas dapat dilihat dalam referensi sebagai berikut: Maftucah Yusuf, Perempuan Agama dan Pembangunan Wacana Kritis atas Peran dan Kepemimpinan Wanita, (Yogyakarta: Lembaga Studi dan Inovasi Pendidikan, 2000), Ramayulis, Ilmu Pendidikan Islam (Jakarta: Kalam Mulia, 2015), hlm. 211-219, Shalah Qazan, Membangun Gerakan Menuju Pembebasan Perempuan (Solo: Era Intermedia, 2001), hlm. 58, Fatima Umar Nasif, Menggugat Sejarah Perempuan, Mewujudkan Idealisme Gender sesuai Tuntunan Islam (Jakarta: CV Cendekia Sentra Muslim, 2001), hlm. 17-36, Asghar Ali Engineer, Hak-hak Perempuan dalam Islam (Yogyakarta: LSPPA, 2000), hlm. 31-34. 
kualitatif adalah bersifat deskriptif dan induktif. ${ }^{21}$ Pemikiran pendidikan Kartini dijelaskan secara deskriptif dengan mengungkapkan dan menjelaskan peristiwa penting yang terjadi dalam kehidupannya.

Pendekatan yang digunakan adalah pendekatan historis dan biografi.suatu pendekatan yang menceritakan kembali sejarah dan peristiwa penting yang menekankan pada kronologi cerita yang sistematis. ${ }^{22}$ Berpijak pada penelaahan sumber sejarah, perekaman informasi, pengevaluasian sumber sejarah, dan interpretasi sumber sejarah. ${ }^{23}$

Sumber data primer yang digunakan dalam penelitian ini adalah Kumpulan surat-surat Kartini dalam buku Habis Gelap Terbitlah Terang (Jakarta: Balai Pustaka, 2000) yang diterjemahkan oleh Armijn Pane, dan surat-surat Kartini dalma buku Emansipasi Surat-surat Kepada Bangsanya 1899-1904 (Yogyakarta: Jalasutra, 2014) yang diterjemahkan oleh Sulastin Sutrisno.

Sumber data sekunder peneliti menggunakan literatur kepustakaan yang mengkaji tentang pemikiran Kartini dan penelitian lapangan di Museum Kartini Jepara dan SD Sarirejo Kartini sebagai sekolah Kartini pertama yang didirikan pada tahun 1913 oleh yayasan Van Deventer setelah wafatnya Kartini.

Penelitian ini menggunakan telaah dokumen sebagai metode pengumpulan datanya, yaitu mencari hal-hal mengenai pemikiran Kartini baik berupa catatan, transkip, buku, surat kabar, majalah, prasasti, dan sebagainya. ${ }^{24}$ Analisisnya menggunakan metode content analysys yaitu teknik penelitian yang dimanfaatkan untuk menarik kesimpulan yang replikatif dan sahih dari data yang diperoleh.

Adapun langkah-langkah yang dilakukan adalah: 1) pemilihan topik, 2)

21 Lexy Meleong, Metode Penelitian Kualitatif (Bandung: PT Remaja Rosdakarya, 2004), cet. Ke-32, hlm. 10.

22 John W. Creswell, Penelitian Kualitatif dan Desain Riset Memilih di antara Lima Pendekatan, (Yogyakarta: Pustaka Pelajar, 2014), hlm. 96-104.

23 Suharsimi Arikunto, Manajemen Penelitian (Jakarta: Rineka Cipta, 2007), hlm. 260

24 Suharsimi Arikunto, Prosedur Penelitian Suatu Pendekatan Praktik (Jakarta: Rineka Cipta, 2002), cet. keduabelas, hlm. 206. pengumpulan data-data tentang pemikiran Kartini, 3) penelaahan pemikiran Kartini tentang pendidikan perempuan secara menyeluruh, 4) penelaahan pemikiran tentang pendidikan perempuan secara komprehensif, 5) menganalisis hubungan pemikiran Kartini tentang pendidikan perempuan dengan pendidikan Islam, 6) menganalisis pemikiran Kartini dalam pengembangan pendidikan Islam, 7) penyimpulan.

\section{HASIL DAN PEMBAHASAN}

Sebelumnya telah banyak ditemukan berbagai penelitian tentang Kartini, namun penelitian-penelitian sebelumnya memiliki objek dan hasil penelitian yang berbeda dengan penelitian ini. Penelitian-penelitian sebelumnya mengambil objek dan hasil penelitian tentang pemaknaan surat-surat Kartini yang telah diterjemahkan dalam bahasa inggris seperti penelitian yang dilakukan Frances Gouda (1998, Jean Gelman Taylor (1994), Hendrik M.J. Maier (1988) Kathy Rabinson (1989) dan Anne Lawrence (2015) yang berusaha membandingkan suratsurat Kartini dengan salah seorang Feminis Australia. Penelitian lain banyak mengkaji tentang realisasi mimpi-mimpi Kartini pada masa sesudahnya yang diperjuangkan oleh keempat adiknya yaitu Rukmini, Kardinah, Kartinah dan Sumantri, sehingga mereka menjadi perempuan sebagaimana yang dicita-citakan Kartini. Perempuan yang memiliki peran penting bagi keluarga dan masyarakat, seperti penelitian yang dilakukan oleh Tineke Hellwig (2008), Doreen Lee (2008), dan Elsbeth Locher Scholten (2011), dan Barbaya W.A. (2013) mengkaji tentang suara-suara perempuan di wilayah Asia yang salah satunya mengkaji Kartini dalam realisasi cita-cita Kartini yang telah dilakukan oleh keempat adiknya.

Penelitian-penelitian yang baru juga memiliki objek dan hasil penelitian yang berbeda dengan penelitian yang dilakukan penulis, seperti penelitian Petra Mahy (2012) yang mengkaji tentang menjadi seorang Kartini masa kini dengan melihat peringatan-peringatan Hari Kartini dan memaknai kembali fungsi perayaannya. Penelitian lain adalah penelitian 
Nurmahmudah (2015) yang mengkaji tentang pengalaman religius Kartini yang ditinjau dalam pandangan filsafat agama. Penjelasan di atas memberikan pemahaman kembali bahwa penelitian ini memiliki perbedaan dengan penelitian-penelitian sebelumnya yang menekankan pendidikan perempuan Kartini baik konsep maupun praktiknya dan relevansinya dengan pengembangan pendidikan Islam.

\section{Konsep Pendidikan Perempuan Kartini}

Pendidikan bagi Kartini merupakan suatu alat yang digunakan untuk membuka pikiran masyarakat ke arah modernitas. Suatu langkah menuju peradaban yang maju, dimana laki-laki dan perempuan saling bekerjasama untuk membangun bangsa. Persamaan pendidikan merupakan salah satu bentuk kebebasan kepada perempuan. kebebasan yang dimaksud adalah kekebasan untuk berdiri sendiri, menjadi perempuan yang mandiri, menjadi perempuan yang tidak bergantung pada orang lain. ${ }^{25}$

Tujuan pendidikan perempuan Kartini adalah menjadikan perempuan sebagai perempuan yang cakap dan baik, yang sadar akan panggilan budinya, sanggup menjalankan kewajibannya yang besar dalam masyarakat. Agar dalam masyarakat menjadi ibu yang baik, pendidik yang bijaksana, pengatur rumah tangga yang mampu memegang keuangan, serta pembantu yang baik bagi siapapun yang memerlukan bantuan. ${ }^{26}$

Pendidikan pertama seorang anak adalah berasal dari keluarga.Ibu memiliki peran yang sangat penting dalam memberikan pendidikan kepada anak sejak dini. ${ }^{27}$ Seorang ibu yang terdidik akan memberikan pendidikan yang baik kepada anaknya sehingga terbentuklah kecerdasan

25 Surat kepada Stella Zeehandelaar 25 Mei 1899 dalam Armijn Pane, Habis Gelap, hlm. 34.

26 Nota R.A. Kartini kepada Pemerintah, Lampiran Surat Permohonan 19 April 1903 dalam Sulastin Sutrisno, Emansipasi, hlm. 566.

27 Surat kepada Nyonya Ovink Soer awal tahun 1900 dalam Armijn Pane, Habis Gelap, hlm. 47. Dapat pula dibaca pada Surat Kepada Nyonya Abendanon 21 Januari 1901 dalam Armijn Pane, Habis Gelap, hlm. 78-79. dan budi pekerti pada anak. ${ }^{28}$ Selain itu, seorang ibu hendaknya tidak membedabedakan pendidikan antara anak laki-laki dan perempuan. ${ }^{29}$

Pendidik di sekolah yang disebut guru, harus memposisikan dirinya sebagai ibu dari anak didiknya.Jangan sampai, seorang guru yang dikenal hanya karena telah memberikan ilmu pengetahuan semata, melainkan juga seorang guru yang memiliki kedekatan emosional yang penuh kasih sayang kepada anak didiknya sehingga dapat membentuk budi pekerti. ${ }^{30}$

Pendidikan budi pekerti tidak hanya diberikan kepada anak-anak, melainkan pula orang dewasa.Metode -metode yang digunakan dapat berupa bacaan-bacaan yang memikat hati, ${ }^{31}$ nyanyian, dongeng, mainan yang dapat memberikan didikan kepada anak didik. ${ }^{32}$ Materi yang diajarkan berupa ilmu pengetahuan umum membaca dan menulis, pendidikan kejuruan bagi perempuan seperti menjahit, merenda, pendidikan kesehatan, pendidikan rumah tangga, dan diberikan pula pendidikan budi pekerti. ${ }^{33}$

\section{Praktik Pendidikan Perempuan di Sekolah Kartini Semarang}

Sekolah Kartini pertama kali dibuka Oleh Kartini dan Rukmini pada tahun 1903. Mula-mula muridnya hanya 9 orang, sedikit demi sedikit muridnya bertambah. Materi yang diajarkan berupa membaca, menulis, menjahit, merenda, dan sebagainya seperti konsep pendidikan yang digagas Kartini tanpa melibatkan kurikulum pemerintah, karena tujuan Kartini bukan hanya memberikan pendidikan umum saja melainkan pula pendidikan budi pekerti. Sekolah Kartini juga di buka di Rembang

28 Raden Ajeng Kartini, "Berilah Orang Jawa Pendidikan" ditulis di Jepara Januari 1903 dalam Sulastin Sutrisno, Emansipasi, hlm. 534.

29 Surat kepada Stella Zeehandelaar 23 Agustus 1899 dalam Sulastin Sutrisno, Emansipasi Surat, hlm. 86.

30 Surat kepada Nyonya Abendanon 02 September 1902 dalam Armijn Pane, Habis Gelap, hlm. 149-150.

31 Raden Ajeng Kartini, Berilah Orang Jawa Pendidikan, hlm. 540 .

32 Surat kepada Nyonya vam Kol 20 Agustus 1902 dalam Armijn Pane, Habis Gelap, hlm. 147.

33 Surat kepada Nyonya Van Kol Agustus 1901 dapat pula dibaca Surat kepada Stella Zehandelaar 20 Mei 1901 dalam Armijn Pane, Habis Gelap, hlm. 83. 
setelah Kartini menikah dan mengikuti suaminya. Namun, pada akhirnya sekolah Kartini harus dibubarkan karena kekurangan dana finansial. ${ }^{34}$

Setelah wafatnya Kartini, diadakan pengumpulan dana Kartini yang digunakan untuk membangun sekolah Kartini seperti yang dicita-citakan olehnya. Sehingga pada tahun 1913 didirikanlah sekolah Kartini pertama di Semarang dan Jakarta, kemudian

34 Redja Mulyohardjo, Pengantar Pendidikan Sebuah Pengantar tentang Dasar-dasar Pendidikan pada Umumnya dan Pendidikan di Indonesia (Jakarta: PT Raja Grafindo Persada, 2012), hlm. 284. disusul sekolah Kartini di beberapa daerah lain. Hingga saat ini, sekolah Kartini tetap eksis salah satunya yaitu sekolah Kartini pertama di Semarang yang sekarang berganti nama menjadi SD Sarirejo Kartini Semarang. ${ }^{35} \mathrm{Di}$ bawah ini dipaparkan tentang hasil analisis perbandingan konsep pendidikan perempuan Kartini dan praktik pendidikan perempuan pada sekolah Kartini.

35 Bambang Eryudhawan, 100 Tahun Bangunan SD Kartini Semarang 1915-2015 (Semarang: YAD, 2015), hlm. 2.

Matrik I. Perbandingan Konsep Pendidikan Kartini dan Praktik Sekolah Kartini Sekarang

\begin{tabular}{|c|c|c|c|}
\hline Perihal & Konsep Pendidikan Kartini & Praktik Sekolah Kartini & Sesuai/Tidak \\
\hline Kepemilikan & $\begin{array}{l}\text { Sekolah harus diupayakan mi- } \\
\text { lik swasta sehingga mempunyai } \\
\text { sistem kewenangan sendiri }\end{array}$ & $\begin{array}{l}\text { Sekolah telah melebur menjadi milik } \\
\text { pemerintah dimana semua ketentuan } \\
\text { harus mengikuti prosedur dari pe- } \\
\text { merintah nasional }\end{array}$ & Tidak sesuai \\
\hline Tujuan & $\begin{array}{l}\text { Menjadikan perempuan sebagai } \\
\text { perempuan yang cerdas dan ber- } \\
\text { budi, yang tidak hanya berperan } \\
\text { di dalam keluarga namun juga } \\
\text { di masyarakat sebagai pembawa } \\
\text { peradaban }\end{array}$ & $\begin{array}{l}\text { Visi sekolah adalah terwujudnya se- } \\
\text { kolah yang peduli dan berbudaya } \\
\text { lingkungan, unggul dalam prestasi, } \\
\text { luhur dalam budi pekerti, dan ber- } \\
\text { wawasan global demi terwujudnya } \\
\text { tujuan pendidikan nasional }\end{array}$ & sesuai \\
\hline Pendidik & $\begin{array}{l}\text { Pendidik bukan hanya sebagai } \\
\text { pengajar namun juga sebagai } \\
\text { pendidik yang memposisikan } \\
\text { dirinya selayaknya ibu bagi anak } \\
\text { didiknya }\end{array}$ & $\begin{array}{l}\text { Sebagai motivator, pendorong, yang } \\
\text { tidak hanya mengajar namun mem- } \\
\text { berikan keterampilan dan menanam- } \\
\text { kan budi perkerti }\end{array}$ & Sesuai \\
\hline Metode & $\begin{array}{l}\text { Bacaan, dongeng, nyanyian, per- } \\
\text { mainan yang dapat mendidik } \\
\text { serta diperbolehkannya melaku- } \\
\text { kan hukuman yang tidak bersifat } \\
\text { fisik. }\end{array}$ & $\begin{array}{l}\text { Pembelajaran aktif yang kreatif, ber- } \\
\text { karakter, dan menyenangkan dengan } \\
\text { memanfaatkan sumber lingkungan } \\
\text { hidup, bacaan, dan teknologi }\end{array}$ & Sesuai (lebih baik) \\
\hline Materi & $\begin{array}{l}\text { Ilmu tentang kesehatan dan pen- } \\
\text { yakit, seni, memasak, menjahit, } \\
\text { membaca dan menulis, merenda, } \\
\text { dan mengurus rumah tangga }\end{array}$ & $\begin{array}{l}\text { Materi disesuaikan dengan kuriku- } \\
\text { lum pendidikan nasional. Materi } \\
\text { tambahan dalam ekstrakulikuler } \\
\text { adalah karawitan, paduan suara, } \\
\text { seni tari, dan seni macapat. Dan ket- } \\
\text { erampilan yang lain dalam kegiatan } \\
\text { tertentu seperti lomba-lomba }\end{array}$ & $\begin{array}{l}\text { Sesuai (keterampi- } \\
\text { lan dalam pengem- } \\
\text { bangan yang ber- } \\
\text { beda) }\end{array}$ \\
\hline Bahasa & $\begin{array}{l}\text { Diajarkan penguasaan bahasa Be- } \\
\text { landa dalam setiap aktifitas pem- } \\
\text { belajaran baik membaca maupun } \\
\text { menulis }\end{array}$ & $\begin{array}{l}\text { Terdapat materi pelajaran bahasa In- } \\
\text { ggis yang diperuntukkan bagi kelas } 5 \\
\text { dan } 6\end{array}$ & $\begin{array}{l}\text { Sesuai (kualitas } \\
\text { menurun) }\end{array}$ \\
\hline Lingkungan & $\begin{array}{l}\text { lingkungan pendidikan paling } \\
\text { dasar adalah keluarga, kemudian } \\
\text { lingkungan keluarga membentuk } \\
\text { lingkungan masyarakat sehingga } \\
\text { terciptalah peradaban }\end{array}$ & $\begin{array}{l}\text { Pola hubungan yang harmonis dan } \\
\text { interaktif antara sekolah, anak didik, } \\
\text { dan orang tua sehingga memberikan } \\
\text { rasa kepercayaan satu sama lain }\end{array}$ & Sesuai \\
\hline
\end{tabular}


Gagasan Kartini tentang pendidikan perempuan merupakan wujud kepekaannya terhadap masalah sosial yang telah menjadi virus dan bersarang dalam tubuh masyarakat bumiputra yang berwujud tata hidup feodalisme.Perjuangan Kartini untuk mengangkat pendidikan perempuan sejajar dengan laki-laki memiliki kesesuaian dengan pendidikan Islam.Untuk lebih jelasnya dapat dibaca pada table dibawah ini.

Matrik II. Perbandingan antara Pendidikan Kartini dan

Pendidikan Peremempuan dalam Tinjauan Islam

\begin{tabular}{|c|c|c|c|c|}
\hline No & Jenis & Pemikiran Kartini & Pendidikan Islam & Sesuai/Tidak \\
\hline 1 & $\begin{array}{l}\text { K e d u d u k a n } \\
\text { Perempuan }\end{array}$ & $\begin{array}{l}\text { Kartini memperjuangan } \\
\text { emansipasi untuk mensejajarkan } \\
\text { kedudukan perempuan dengan } \\
\text { laki-laki, sehingga perempuan } \\
\text { dapat menjadi partner berjuang } \\
\text { laki-laki untuk membangun } \\
\text { peradaban bangsa yang lebih } \\
\text { baik }\end{array}$ & $\begin{array}{l}\text { Berdasar QS. al-Hujurat: } 13 \text { maka } \\
\text { kedudukan antara perempuan } \\
\text { dan laki-laki sama di mata Allah } \\
\text { kecuali ketakwaannya. Dan } \\
\text { berdasar QS. an-Nisa: } 34 \text { masing- } \\
\text { masing gender dilebihkan Allah } \\
\text { atas sebagian yang lain, sesuai } \\
\text { peran dan fungsinya. }\end{array}$ & Sesuai \\
\hline 2 & $\begin{array}{l}T \quad u \quad j \quad u \quad n \\
p \text { e } n \text { d i d i k a n } \\
\text { perempuan }\end{array}$ & $\begin{array}{l}\text { Menjadikan sebagai perempuan } \\
\text { yang cakap yang baik, } \\
\text { yang mampu dan terampil } \\
\text { menjalankan kewajibannya } \\
\text { dalam keluarga dan masyarakat } \\
\text { menuju peradaban yang maju } \\
\text { yaitu akhlak dan keagungan } \\
\text { jiwa kepada Allah swt. }\end{array}$ & $\begin{array}{l}\text { Menjadikan umat manusia } \\
\text { sebagai insan kamil yang mampu } \\
\text { menjalankan tugasnya sebagai } \\
\text { manusia seutuhnya, yang sadar } \\
\text { akan hakikat dirinya sebagai hamb } \\
\text { Allah swt. Pendidikan perempuan } \\
\text { bertujuan menjadikan perempuan } \\
\text { sebagai perempuan seutuhnya } \\
\text { yang memiliki kewajiban sebagai } \\
\text { khalifah }\end{array}$ & Sesuai \\
\hline 3 & $\begin{array}{l}\text { Peran Pendidikan } \\
\text { Perempuan }\end{array}$ & $\begin{array}{l}\text { Perempuan memiliki } 2 \text { peran } \\
\text { yaitu dalam keluarga yang } \\
\text { tidak melupakan kodratnya } \\
\text { sebagai seorang istri dan ibu, } \\
\text { dan dalam masyarakat sebagai } \\
\text { pembawa peradaban. Dan } \\
\text { hanya perempuan terdidiklah } \\
\text { yang sanggup menjalankan } \\
\text { kedua peran itu dengan baik. }\end{array}$ & $\begin{array}{l}\text { Dalam keluarga perempuan } \\
\text { terdidik mampu menciptakan } \\
\text { generasi muslim yang kuat } \\
\text { dan membentuk keluarga } \\
\text { sakinah. Dan dalam masyarakat, } \\
\text { perempuan terdidik akan } \\
\text { menciptakan lingkungan yang } \\
\text { sehat berlandaskan Al-Quran dan } \\
\text { as-Sunnah }\end{array}$ & Sesuai \\
\hline
\end{tabular}

Sumber: dari berbagai sumber

3. Kontribusi Kartini dalam Pengembangan Pendidikan Islam

Kekritisan Kartini bukan hanya dalam persoalan sosial masyarakat, namun juga dalam wilayah agama.Ancaman kristenisasi dari para penjajah yang mengajak umat Islam untuk masuk agama mereka disertai dengan jaminan pelayanan sosial, kesehatan, pendidikan, bahkan terkadang juga dilakukan melalui paksaan dapat memecah-belah umat Islam dan merusak pendidikan Islam.Banyak sekolah-sekolah yang didirikan untuk rakyat pribumi yang memiliki makna terselubung yaitu kristenisasi.Kartini banyak menggugat aksi ini melalui suratnya kepada sahabatsahabatnya, namun hal ini tidak mendapat tanggapan yang serius, sehingga Kartini tidak memberi penekanan terhadap ancaman kristenisasi lebih dalam.Selain itu, pada masa Kartini, belum banyak orang yang memiliki pemikiran mengenai bahaya kristenisasi, namun Kartini telah memikirkan lebih dulu.Baru pada periode setelah wafatnya Kartini, ancaman kristenisasi mendapat tanggapan yang serius dari berbagai golongan Islam, dan konflik umat Kristen dan Islam menjadi permasalahan yang serius bagi perkembangan pendidikan Islam.

Pandangan Kartini tentang agama sangat universal.Kartini melihat bukan dari sudut pandang Islam itu sendiri, namun dari kacamata di luar Islam yang melihat 
agama sebagai suatu kepercayaan umum yang dianut oleh seluruh umat manusia. Keterbatasan pengetahuan Kartini tentang Islam, membuatnya bertindak bebas terhadap agama, sehingga banyak terjadi multitafsir di kalangan masyarakat. Kartini pernah mengatakan bahwa ia tidak mau lagi mengerjakan puasa, tidak mau membaca AlQuran karena tidak memahami maknanya, dan ibadah-ibadah lainnya. Kartini tidak memahami mengapa seseorang melaksanakan perbuatan tersebut.Kartini beranggapan bahwa setiap perbuatan yang dilakukan harus memiliki landasan dan sumber yang jelas, sehingga dapat diketahui benar salah, baik dan buruknya suatu perbuatan, bukan atas dasar taklid terhadap kepercayaan nenek moyang.

Masyarakat Islam pada zaman Kartini adalah masyarakat Islam yang memiliki pemahaman dangkal tentang Islam itu sendiri, karena belum banyak yang memiliki pemahaman mendalam tentang ajaran Islam.Bahkan Al-Quran yang merupakan pedoman hidup umat manusia tidak boleh diterjemahkan dan sedikitorang mengetahui makna yang terkandung di dalamnya. Berdasar refleksi kritis Kartini tentang Islam memberikan pemahaman kepada lapisan masyarakat untuk memaknai ajaran Islam secara komprehensif. Islam mulai dimaknai secara lebih dalam, Al-Quran bukan hanya diajarkan cara membacanya saja yang kerap menimbulkan kebosanan kepada penganutnya, namun Al-Quran mulai dipahami beserta makna yang terkandung di dalamnya.

Meskipun Kartini memiliki pamahaman agama yang terbatas, Kartini meyakini bahwa agama memiliki peran yang besar bagi masyarakat dan peradaban manusia. Kartini memang tidak secara eksplisit menyatakan dengan jelas pentingnya agama dalam pendidikan dalam surat-suratnya, namun pemahaman Kartini yang semakin mendalam tentang agama memberikan sebuah pandangan bahwa dasar dari pendidikan seorang anak adalah agama yang baik, yang pertama kali diberikan oleh seorang ibu kepada anak dalam produk perangai dan budi pekerti.
Sekolah Kartini juga tidak melupakan materi agama.Agama dijadikan sebagai materi dasar untuk memahami ilmu pengetahuan yang lainnya.Kartini menekankan penguasaan agama sangat penting.Al-Quran bukan hanya untuk dibaca saja, melainkan juga dipahami maknanya untuk menjawab setiap persoalan zaman.

Sekolah-sekolah Kartini mencapai perkembangan yang cukup signifikan untuk memberikan pemahaman pentingnya pendidikan bagi perempuan, sehingga setelah wafatnya, banyak didirikan sekolahsekolah perempuan serupa sekolah Kartini di berbagai wilayah seperti Ambon, Makassar, Aceh, Medan, dan lain-lain. Bahkan di Padang telah didirikan sekolah Islam modern yang memberikan pendidikan kepada laki-laki maupun perempuan.

Pemikiran-pemikiran dan praktik pendidikan perempuan kepada masyarakat bumiputra merupakan sebuah stimulan tumbuhnya pemahaman dan pengetahuan yang lebih baik, khususnya dalam pendidikan Islam.Seperti yang telah dikemukakan di atas, pendidikan Islam masa Kartini dan masa sebelumnya belum dipahami secara dalam. Kekritisan Kartini tentang Islam memberikan kesadaran kepada para ulama untuk meningkatkan pemahaman Islam kepada masyarakat dengan konsep pendidikan yang jelas, sehingga masa setelah Kartini kurang dari sepuluh tahun, pendidikan Islam mengalami perkembangan yang sangat pesat.

Setelah wafatnya Kartini, banyak sekolah-sekolah Islam didirikan, bukan hanya terbuka untuk anak laki-laki saja namun juga anak perempuan.selain itu, banyak pula didirikan sekolah-sekolah perempuan, khususnya pesantren untuk putri-putri di beberapa wilayah. Juga mulai tumbuhnya golongan-golongan pergerakan Islam yang memiliki pemikiran dan orientasi untuk mengembangkan pendidikan Islam yang progresif dan berkemajuan.Hingga saat ini pendidikan Islam terus mengalami perkembangan-perkembangan yang sangat pesat menuju pendidikan yang mampu menjawab tantangan zaman. 


\section{Pendidikan Vokasi sebagai Reorientasi Pendidikan Perempuan Kartini}

Konsep pendidikan yang digagaskan Kartini telah terwujud pada masa sekarang. Perempuan dapat mengakses pendidikan di mana pun dan kapan pun ia berada,. Perempuan memiliki kebebasan menentukan kehidupannya sendiri dan mampu melangkah mewujukan apa yang ia harapkan. Akses -akses pendidikan bagi perempuan telah terbuka, sehingga perempuan-perempuan Indonesia masa kini dapat meningkatkan jenjang pendidikannya hingga perguruan tinggi. Saat ini telah banyak perempuan yang bergelar profesor, doktor, dan sebagainya. Pada level ini perempuan telah mencapai kesetaraan dengan laki-laki dalam hal pendidikan. Namun, pembicaraan Kartini tidak hanya sampai di sini, meskipun kesetaraan yang dicita-citakan Kartini telah terwujud., generasi penerus bangsa tetap memiliki kewajiban untuk melakukan progres dan perjuangan menuju Indonesia berkemajuan.

Sosok dan gagasan-gagasan Kartini harus dimaknai kembali, khususnya gagasan Kartini tentang pendidikan.Pendidikan adalah alat yang digunakan Kartini untuk memajukan bangsa Indonesia. Pendidikan menjadikan perempuan-perempuan memperoleh kebebasan, yakni kebebasan untuk berdiri sendiri, mandiri, dan tidak bergantung pada orang lain sebagaimana dijelaskan dalam bab III halaman 64 . Kartini sangat menginginkan perempuan memperoleh kemerdekaan baik jasmani maupun rohani, sehingga perempuan mampu mengembangkan kemampuan dan potensi yang dimiliki dalam kehidupannya.

Perjuangan Kartini tentang pendidikan sangat ditekankannya pendidikan kejuruan sebagaimana dilihat dalam bab III halaman 116, bahwa Kartini meminta kepada Abendanon selaku Direktur Departemen Pendidikan, Agama, dan Kerajinan Belanda untuk mendirikan pendidikan kejuruan bagi masyarakat Bumiputra. Kartini berharap, dengan adanya bekal pendidikan kejuruan dapat menjadikan seseorang menjadi seorang yang mandiri, mampu melaksanakan segala sesuatu tanpa menjadikan dirinya beban bagi orang lain. Pada praktik pendidikannya, Kartini memberikan beberapa keterampilan kepada murid-muridnya, seperti menjahit, merenda, memasak, dan sebagainya sebagai bekal kepada perempuan dalam berkeluarga dan bermasyarakat.

Pada masa sekarang, pendidikan kejuruan lebih dikenal sebagai pendidikan vokasi. Pendidikan vokasi adalah suatu pendidikan yang mengasah skill dan kemampuan seseorang, untuk meningkatkan kecakapan personal, sosial, intelektual, sikap, dan kecakapan vokasi yang memungkinkan pembelajar dapat hidup secara mandiri dan tidak tergantung pada orang lain. Selain itu, pendidikan vokasi juga bertujuan untuk memenuhi persaingan pasar kerja yang berkualitas. sehingga seseorang, mau dan berani dalam menghadapi berbagai permasalahan hidup dan mampu mengatasinya dengan solusisolusi kreatif.

Pendidikan vokasi Kartini untuk meningkatkan kecakapan personal perlu diupayakan pembentukan budi pekerti. Kartini menyatakan bahwa peradaban yang maju bukan hanya ditentukan oleh tingginya ilmu pengetahuan, melainkan pula tingginya budi pekerti sebagaimana dijelaskan dalam bab III halaman 134. Kartini hendak menyatakan bahwa akhlak memainkan peranan yang sangat penting dalamkehidupanmanusia.Akhlak tidakbisa timbul dengan sendirinya, melainkan perlu latihan secara terus-menerus dan berulangulang hingga tumbuh di dalam kejiwaan seseorang.Hal ini dapat dilihat pada budi pekerti Kartini yang sopan, santun, lembut, hormat, bijaksana, semangat, penyayang, pemberani, toleran, dan sebagainya.Kartini adalah seorang bangsawan yang memiliki kewajiban untuk memberikan teladan yang baik kepada rakyatnya.Sifat-sifat Kartini sebagai perempuan yang sesungguhnya harus diteladani oleh masyarakat sekarang, bahwa ilmu pengetahuan harus diikuti dengan akhlak dan budi pekerti yang luhur.

Dalam hal intelektual, Kartini adalah sosok pembelajar yang sejati.Kartini sangat gemar membaca.Banyak sekali-buku-buku dan segala sumber bacaan menjadi pusat perhatian Kartini.Bukan hanya dibaca 
saja, melainkan juga dengan pemahaman, penelaahan, dan penulisan kembali apa-apa yang telah dibacanya secara menyeluruh ke dalam gagasan-gagasannya sendiri.Kartini mengambil sari pati dari kebudayaan yang baik, kemudian mengasimilasikan dengan budaya Indonesia.Pendidikan saat ini memiliki akses yang cepat dengan adanya arus globalisasi. Perkembangan yang semakin pesat dan maju harus diiringi dengan tingkat intektualitas yang tinggi pula, sehingga tidak tertinggal dengan negara-negara lain. Intelektualitas juga memiliki peran penting untuk menciptakan peradaban bangsa yang berkemajuan di era digital.

Selain kecakapan personal dan intelektual, pendidikan vokasi juga mengembangan kecakapan vokasional. Kartini menekankan pendidikan keterampilan bagi perempuan dengan memesak, menjahit, merenda, dan keterampilan lain yang mempu menunjang kemandirian perempuan. Perempuan harus bebas, di mana kebebasan ini berupa kemerdekaannya sebagai perempuan. Perempuan tidak terikat dalam budayabudaya yang mengekang kehidupannya. Dengan keterampilan itu perempuan dapat mandiri dan tidak menjadi beban bagi orang lain. Saat ini pendidikan vokasional merupakan praktik keahlian terapan meliputi kejuruan di berbagai bidang untuk memiliki kemahiran dan keahlian tertentu di bidangnya masing-masing, sehingga perempuan mampu bersaing dengan laki- laki dalam dunia kerja, menghasilkan tenaga kerja terampil dan memiliki kualifikasi yang baik dengan kesiapan ilmu yang dimiliki dam seperangkat dorongan untuk berprestasi.

\section{PENUTUP}

Konsep pendidikan Kartini berupa konsep pendidikan praktis dan aplikatif tentang pendidikan perempuan. konsep pendidikan Kartini bukan hanya anganangan semata melainkan sebuah ide yang direalisasikan dalam kehidupan dengan bibukanya Sekolah Kartini untuk perempuan. Akibat perjuangan Kartini yang heroik di tengah masyarakat Jawa yang masih memegang teguh adat feodalisme memberikan stimulant pengembangan pendidikan padamasaberikutnyakhususnya pendidikan Islam, sehingga tidak lama setelah wafatnya Kartini banyak tumbuhnya pemikir-pemikir Islam yang progresif dalam mengembangkan pendidikan Islam dengan lahirnya berbagai gerakan organisasi keagamaan yang bergerak dalam politik, sosial, maupun pendidikan. Berdasar kesimpulan di atas, maka hendaknya setiap orang khususnya kepada perempuan dapat memposisikan dirinya dengan baik dalam keluarga maupun masyarakat untuk membentuk peradaban yang berkemajuan dengan melahirkan generasi muslim yang kuat dalam Iman takwa (IMTAK) dan Ilmu Pengetahuan dan Teknologi (IPTEK)

\section{DAFTAR PUSTAKA}

Arikunto, Suharsimi. 2007. Manajemen Penelitian. Jakarta: Rineka Cipta. , 2002.Prosedur Penelitian Suatu Pendekatan Praktik. Jakarta: Rineka Cipta.

Basri, Hasan. 2013. Landasan Pendidikan. Bandung: Pustaka Setia.

Creswell, John W. 2014. Penelitian Kualitatif dan Desain Riset Memilih di antara Lima Pendekatan. Yogyakarta: Pustaka Pelajar.

Engineer, Asghar Ali.2000. Hakhak Perempuan dalam Islam. Yogyakarta: LSPPA.

Eryudhawan, Bambang. 2015. 100 Tahun Bangunan SD Kartini Semarang 1915-2015.Semarang: YAD.

Hasbullah. 1999. Dasar-dasar Ilmu Pendidikan. Jakarta: PT Raja Grafindo Persada.

Herawati, Ida Siti. 2003. "Pendidikan yang Berperspektif Gender pada Jenjang Sekolah Dasar" dalam Sugiarti, dkk. Pembangunan dalam Perspektif Gender.Malang: UMM 
Press.

Ihsan, Fuad. 2010. Dasar-dasar Kependidikan Komponen MDMK. Jakarta: Rineka Cipta.

Johnson, Doyle Paul. 1990. Teori Sosiologi Klasik dan Modern.Jakarta: PT Gramedia Pustaka Utama.

Khawari, Nurul. 2012. Kartini dan Perempuan Muda Indonesia. Koran (Online) Joglo Semar (http://www.komnasperempuan.go.id/tafsir-perempuan-untuk-kartini/ dalam Gatra, diakses 11 Oktoober 2016). Edisi khusus.

LPPI Makasar. 2013. R.A. Kartini Versus Aisyah We Tenriolle (http://www.lppimakassar. com/2013/05/ra-kartini-versus-aisyah-we-tenriollle.html, diakses 11 Oktober 2016)

Megawangi, Ratna. 1999. Membiarkan Berbeda? Sudut Pandang Baru tentang Relasi Gender. Bandung: Mizan.

Meleong, Lexy. 2004. Metode Penelitian Kualitatif. Bandung: PT Remaja Rosdakarya.

Mulyohardjo, Redja. 2012. Pengantar Pendidikan Sebuah Pengantar tentang Dasar-dasar Pendidikan Pada Umumnya dan Pendidikan di Indonesia.Jakarta: PT Raja Grafindo Persada.

Mu'thi, Abdul. 2002. Mitos-mitos Perempuan Kurang Akal. Yogyakarta: Gama Media.

Nasif, Fatima Umar. 2001. Menggugat Sejarah Perempuan, Mewujudkan Idealisme Gender Sesuai Tuntunan Islam. Jakarta: CV Cendekia Sentra Muslim.

Nata, Abuddin. 1997. Filsafat Pendidikan Islam. Jakarta: Logos Wacana Ilmu.

Pane, Armijn. 2000. Habis Gelap Terbitlah Terang. Jakarta: Balai Pustaka.

Poloma, Margareth M. 1994. Sosiologi KOntemporer. Jakarta: PT Raja Grafindo Persada.

Qazan, Shalah. 2001. Membangun Gerakan Menuju Pembebasan Perempuan. Solo: Era Intermedia.

Ramayulis. 2015. Ilmu Pendidikan Islam. Jakarta: Kalam Mulia.

Said, Nur. 2014. Politik Etis Kepahlawanan R.A. Kartini: Menguak Spiritualisme Kartini yang Digelapkan. Jurnal Palastren. Vol. 7.No. 2.

Sartono, dkk. 1987. Perkembangan Peradaban Priyayi. Yogyakarta: Gajah Mada University Press.

Sofia, Hanni. 2014. Surat Kartini antara Inspirasi dan Apatisme Bangsa. Koran (Online) Antara Sumsel (http://www.antarasumsel.com/berita/285823/surat-kartini-antara-inspirasidan-apatisme-bangsa, diakses 01 Oktober 2016)

Sudrajat. 2007. Kartini: Perjuangan dan Pemikirannya. Jurnal Mozaik. Vol. 2.No. 2.

Suparno, Suhaenah. 2001. Wanita dan Pendidikan, Kasus di Indonesia. Yogyakarta: Sunan Kalijaga Press.

Suryosubroto.2010. Beberapa Aspek Dasar-dasar Kependidikan.Jakarta: Rineka Cipta.

Sutrisno, Sulastin. 2014. Emansipasi Surat-surat Kepada Bangsanya 1899-1904.Yogyakarta: Jalasutra.

Suwarno, Wiji. 2006. Dasar-dasar Ilmu Pendidikan. Yogyakarta: ar-Ruzz Media.

Undang-Undang Sistem Pendidikan Nasional Np. 20.Tahun 2003.

Yusuf, Maftuchah. 2000. Perempuan Agama dan Pembangunan, Wacana Kritis atas Peran dan Kepemimpinan Wanita. Yogyakarta: Lembaga Studi dan Inovasi Pendidikan 